\title{
Silver-Enhanced in Situ Hybridization
}

National Cancer Institute

\section{Source}

National Cancer Institute. Silver-Enhanced in Situ Hybridization. NCI Thesaurus. Code C142344.

A type of in situ hybridization that uses a hybridization probe linked to an enzyme that elicits neutralization and deposition of silver onto the probe target site. 